\title{
Investigation of Flavonoid and Polyphenol Contents of Lettuce Grown in Katsina State, Nigeria
}

\author{
Gnimintakpa Joseph ${ }^{*}$, Umar Sabiu1, Muhammad Sani ${ }^{2}$ \\ ${ }^{1}$ Federal University Dutsinma, Dutsinma, Nigeria \\ ${ }^{2}$ Institute of Mathematical Research, University Putra, Serdan, Malaysia \\ Email: *gniminsco@yahoo.co.uk
}

How to cite this paper: Joseph, G., Sabiu, U. and Sani, M. (2017) Investigation of Flavonoid and Polyphenol Contents of Lettuce Grown in Katsina State, Nigeria. Open Access Library Journal, 4: e2934. https://doi.org/10.4236/oalib.1102934

Received: July 28, 2017

Accepted: September 12, 2017

Published: September 15, 2017

Copyright ( $\odot 2017$ by authors and Open Access Library Inc.

This work is licensed under the Creative Commons Attribution International License (CC BY 4.0).

http://creativecommons.org/licenses/by/4.0/

\section{c) (†) Open Access}

\begin{abstract}
While it is clear that dietetic choices and habits are contributing to health state of individuals, mounting evidence suggests the biomolecular contents of foods vary in line with the nutritional milieu. Even when it is hard to distinguish the causal factors of this variation, various concentrations of flavonoids or polyphenols in lettuce contribute to preventive strategies of several health conditions. The aim of this study is to investigate flavonoids and polyphenol contents of lettuce grown in katsina state, Nigeria and their potential beneficial role in immunocompetence of consumers.
\end{abstract}

\section{Subject Areas}

Nutrition

\section{Keywords}

Investigate, Flavonoid and Polyphenol Contents, Lettuce, Katsina State, Nigeria

\section{Introduction}

Vegetables contain most, if not all, of the essential components of human nutrition. Nutrients have traditionally been viewed as food components that either cannot be synthesized in the body (for example, vitamin C) or whose synthesis requires a specific factor that may in certain circumstances be absent or inadequate (for example, some amino acids, fatty acids, and vitamins). In vegetables however, there is now recognition that many other compounds of plant food, such as dietary fiber, flavonoids, sterols, phenolic acids, and glucosinolates, are associated with lower disease risk. A large number of phytochemicals capable of 
antioxidant, antimutagenic, cytotoxic, antifungal, and antiviral activities have been identified in lettuces (Prior and Cao, 2000; Goldberg, 2003) [1] [2]. These phytochemicals are associated with many positive effects on human health, including prevention of coronary heart diseases, diabetes, high blood pressure, cataracts, degenerative diseases, and obesity (Liu et al., 2000; Djouss' et al., 2004 [3] [4]. The links between fruit and vegetable consumption and protection against cancers of stomach, esophagus, lung, pharynx, endometrium, pancreas, and colon have also been extensively reported (Temple and Gladwin, 2003; Hung et al., 2004) [5] [6]. The realization of the importance of plant products to the human diet has led to the five-a-day campaign in the United Kingdom to persuade people to eat at least 5 portions of vegetables every day. This campaign is driven by the nutritional importance of plant foods in terms of essential nutrients, trace elements, and fiber (WHO, 2002; WHO, 2003) [7] [8].

Nutrient composition of vegetables is very complex and difficult to assess. Levels of plant metabolites are strongly affected by genetic and environmental factors as well as transportation and storage conditions. Growth factors such as light, temperature, humidity, type of soil, application of fertilizers, damage caused by microorganisms and insects, stress induced by UV radiation, heavy metals, and pesticides all alter metabolite composition of plants (Orcutt and Nilsen, 2000) [9]. Before vegetables appear on a supermarket shelf they might have been handled by plant growers, transporters, packagers, storehouse operators, distributors, and/or processors. The chemical and physical changes that occur in vegetables during these stages can lead to loss of potentially beneficial components (Mac Evilly and Peltola, 2003) [10]. Over the past decade, significant amounts of information have been accumulated on identification, biochemical characterization, localization, and health benefits of plant metabolites. The diverse variety of organic compounds in vegetables represents the product of primary and secondary plant metabolism. Primary metabolites such as carbohydrates, amino acids, fatty acids, and organic acids are involved in growth and development, respiration and photosynthesis, and hormone and protein synthesis. Primary metabolites are found across all species within broad phylogenetic groups, and are produced using the same (or nearly the same) biochemical pathways. Secondary metabolites such as flavonoids, carotenoids, sterols, phenolic acids, alkaloids, and glucosinolates determine the color of vegetables, protect plants against herbivores and microorganisms, attract pollinators and seed-dispersing animals, and act as signal molecules under stress conditions (Seiger, 1998; Crozier et al., 2006) [11] [12]. These metabolites are often differentially distributed among taxonomic groups within the plant kingdom. This research is therefore conducted to determine the total polyphenol and total flavanoids content in Lettuce grown in Katsina state and show their immunotherapeutic and pharmacologic efficacy.

\section{Materials and Methods}

Agriculture is a mainstay of the small scale farmers in Nigeria. (Giroh, et al., 
2010) [13] had posited that Agricultural production in Nigeria is dominated by small scale farmers and is known to produce more than $90 \%$ of food consumed in the country. One of the major items produced is lettuce. The importance of lettuce as major and efficient sources of micronutrients in African diet cannot be over stressed. They are nourishing foods because they contain a little of all the substances man needs; protein, mineral salts, sugars, vitamins, aromatics, coloring agents, iron and essential oils that increase man's resistance to disease. In this class of food, man finds the wide range of nutritive elements he needs. Lettuce is therefore a complementary food of the first order, and is much more important for man's health than products of animal origin (Hugues and Philippe, 1995) [14] as it contains flavonoids and polyphenols in addition to other biochemical compounds.

Polyphenols form a group of compounds containing numerous phenolic groups, among them are flavanoids which play various roles in the management of diseases.

\subsection{Sample Collection}

The vegetables were collected from different farms from six different local governments of Katsina state namely Dutsinma and Jibia (Katsina Zone), Kankara and Faskari (Funtua Zone), Daura and Kankia (Daura Zone) during the month of January 2015. Four samples of lettuce were collected from different wards of the local governments (Table 1).

\subsection{Reagents}

Methanol, distilled water, 10\% aluminium chloride, $1 \mathrm{M}$ potassium acetate, Quercetin, Folin-Ciocalteu reagent, $1 \mathrm{M}$ sodium trioxocarbonate (v) and Gallic acid were used for this study.

\subsection{Preparation of Samples}

The vegetables were dried in an envelope, exposed to sun light in Dutsinma local government area of Katsina State. The first drying started on 27 January, and ended on March $20^{\text {th }} 2015$ while the second drying began on $22^{\text {nd }}$ April and ended on $1^{\text {st }}$ May. The dried lettuce was pulverized to powder using an electric blender in New Biology laboratory complex of Federal University Dutsin-ma in Katsina State.

\subsection{Extraction}

The method of Atawodi and Onaolapo (2010) [15] was adopted for plant extraction. $100 \mathrm{mg}(0.1 \mathrm{~g})$ of the Sample was measured and placed in test tubes, $5 \mathrm{ml}$ of absolute methanol was added and then the test tube was covered with an Aluminum foil. The solution was incubated for 2 hours at $37^{\circ} \mathrm{C}$. Every 15 minutes, the solution was shaken by turning upside down three (3) times with the thumb holding the test tube mouth over the aluminum foil. At the end of the 2 hours, 
the solution was allowed to stand at room temperature for 15 - 30 minutes, the methanolic solution was decanted into clean tubes, capped and stored in the deep freezer at $2^{\circ}$ Celsius for analysis (Table 2).

Table 1. Collection of samples.

\begin{tabular}{|c|c|}
\hline Local govt./ward & \\
\hline \multicolumn{2}{|l|}{ KATSINA ZONE } \\
\hline JIBIA & LETTUCE \\
\hline Gadirge & Collected \\
\hline Hushin buku & Collected \\
\hline Kwamin gabas & Collected \\
\hline Jibia & Collected \\
\hline DUTSINMA & LETTUCE \\
\hline Makera & Collected \\
\hline Badole & Collected \\
\hline Dutsinma & Collected \\
\hline Kofa & Collected \\
\hline \multicolumn{2}{|l|}{ FUNTUA ZONE } \\
\hline FASKARI & LETTUCE \\
\hline Mai ruwa & Collected \\
\hline Mai gora & Collected \\
\hline Kadisau & Collected \\
\hline Bare bari & Collected \\
\hline KANKARA & LETTUCE \\
\hline Zango & Collected \\
\hline Yar tsamiya & Collected \\
\hline Kahi & Collected \\
\hline Kankara & Collected \\
\hline \multicolumn{2}{|l|}{ DAURA ZONE } \\
\hline KANKIA & LETTUCE \\
\hline Sabuwar Abuja & Collected \\
\hline Unguwar gabas & Collected \\
\hline Gachi & Collected \\
\hline Kanti & Collected \\
\hline DAURA & LETTUCE \\
\hline Daura & Collected \\
\hline Dan nakola & Collected \\
\hline Mazoji & Collected \\
\hline Rogogo & Collected \\
\hline
\end{tabular}


Table 2. Concentration of flavanoid and polyphenol from lettuce grown in six local governments of Katsina State.

\begin{tabular}{ccc}
\hline Local government & Flavanoids $(\mathrm{mg}$ QE/g) & Polyphenol $(\mathrm{mg}$ GAE/g) \\
\hline Jibia & $125.07 \pm 28.19^{\mathrm{a}}$ & $104.34 \pm 29.64^{\mathrm{a}}$ \\
Dutsinma & $223.82 \pm 10.61^{\mathrm{c}}$ & $135.93 \pm 20.93^{\mathrm{ab}}$ \\
Kankara & $190.20 \pm 28.01^{\mathrm{bc}}$ & $176.26 \pm 4.55^{\mathrm{bc}}$ \\
Faskari & $205.98 \pm 28.01^{\mathrm{bc}}$ & $149.59 \pm 21.14^{\mathrm{ab}}$ \\
Daura & $130.42 \pm 14.63^{\mathrm{a}}$ & $130.34 \pm 13.05^{\mathrm{ab}}$ \\
Kankia & $155.52 \pm 5.96^{\mathrm{ab}}$ & $216.96 \pm 6.64^{\mathrm{c}}$ \\
\hline
\end{tabular}

\section{Statistical Analysis}

Total polyphenol and total flavonoids were determined from quercetin and gallic acid standard curves as depicted in Figure 1 and Figure 2 respectively. The quercetin standard curve is equated to $\mathrm{y}=0.00881 \mathrm{x}-0.07$ where $\mathrm{y}$ is the absorbance reading of the sample at the wavelength of $415 \mathrm{~nm}$, and $\mathrm{x}$ is the total flavonoid content while the gallic acid standard curve represents $y=0.00593 \mathrm{x}+$ 0.122 where $y$ is the absorbance reading of the sample at the wavelength of 765 $\mathrm{nm}$ and $\mathrm{x}$ is the total polyphenol content of the sample. ANOVA was used in the comparison of the results of total flavonoid and total polyphenol concentrations of these vegetables and also for the comparison of the results from the local government areas, and the means are also taken in both cases.

The results presented in Table 1 indicate that flavanoid concentration of lettuce from Dutsinma is significantly high $(\mathrm{p}<0.05)$ while the lettuce from Jibia and Daura had significantly low $(\mathrm{p}<0.05)$ concentrations of flavonoid (Figures $3-5)$. The lettuce from Kankia had significantly high $(\mathrm{P}<0.05)$ concentration of polyphenol (Figures 3-5) while that from Jibia had significantly lower $(\mathrm{p}<0.05)$ concentration of polyphenol (Figures 3-5).

Table 3 depicts a t-value of 0.844 obtained and a P-value of 0.419 at the degree of freedom of 10 . The critical P-value of 0.419 is greater than the alpha value of 0.05 . This indicates that overall there is no significant difference between flavanoid and polyphenol contents of the six local governments areas of interest. Thus, the null hypothesis that there is no significant difference between flavanoid and Polyphenol contents in lettuce from the six local government areas of Katsina state was conclusively accepted.

\section{Discussion}

The concentrations of polyphenol and flavonoids in lettuce highly produced and consumed in Katsina were investigated. It may be important to substitute synthetic antioxidants with naturally identified antioxidants sources from locally available Lettuce as they are less toxic and easily affordable compared to synthetic antioxidants (Osawa, 1994) [16]. Several reports have conclusively shown a correlation between the antioxidant activity and amount of total phenolics or total flavonoids (Sun, 2002; Ramadeep and Geoffrey, 2005: [17] [18]). Here also 


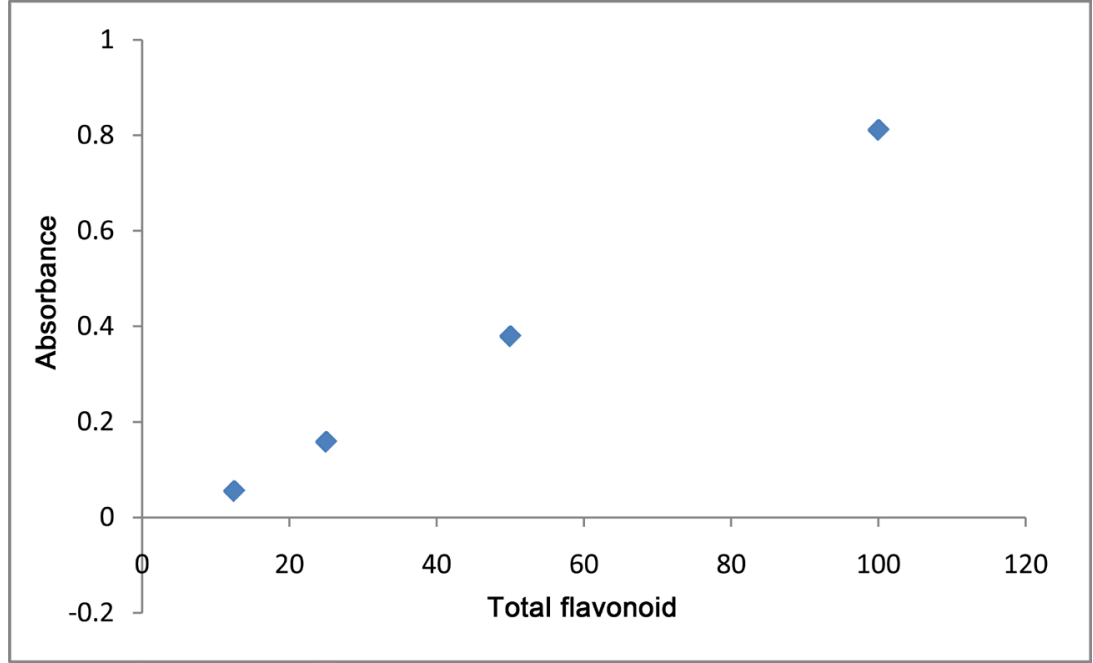

Figure 1. Quercetin standard curve.

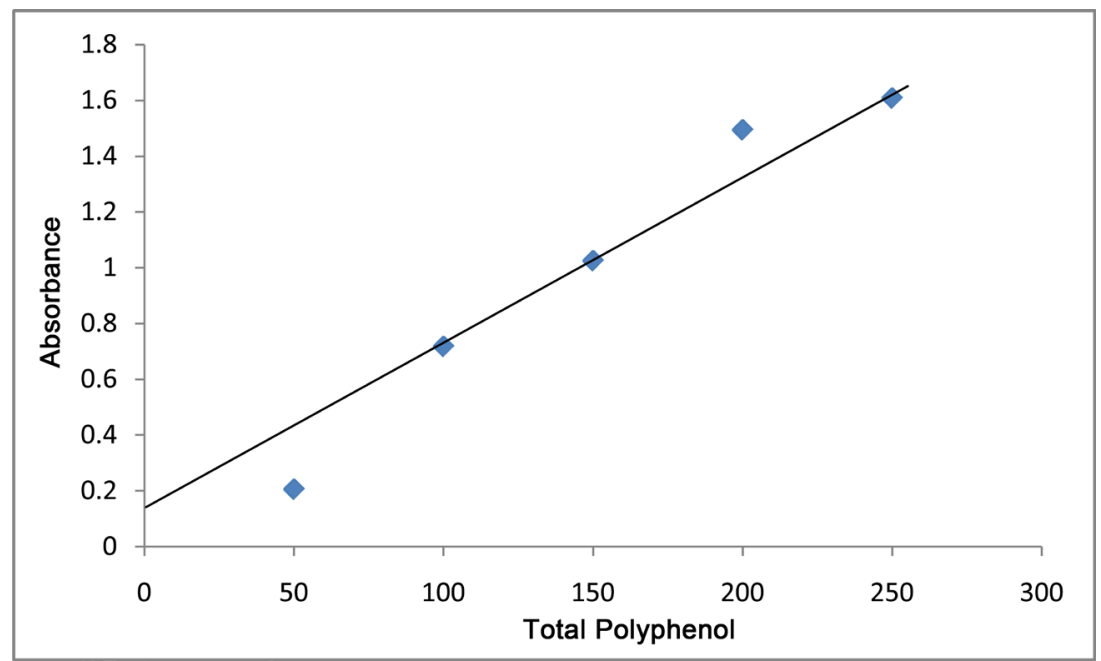

Figure 2. Gallic acid standard curve.

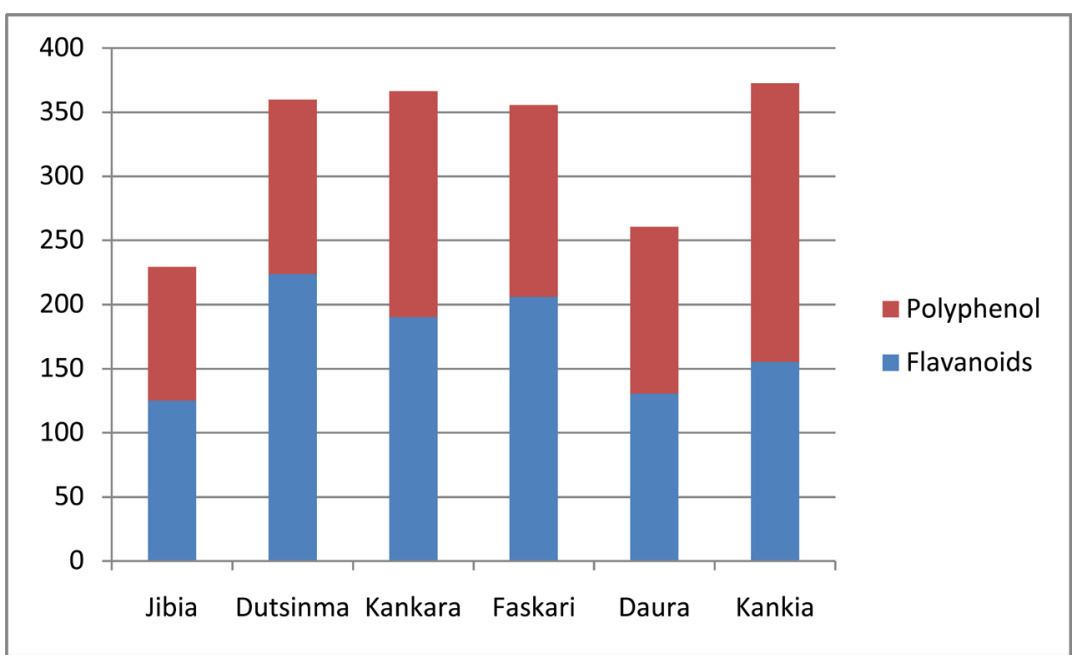

Figure 3. Bar graph of flavonoid and Polyphenol contents in lettuce from six local Governments of Katsina State, Nigeria. 


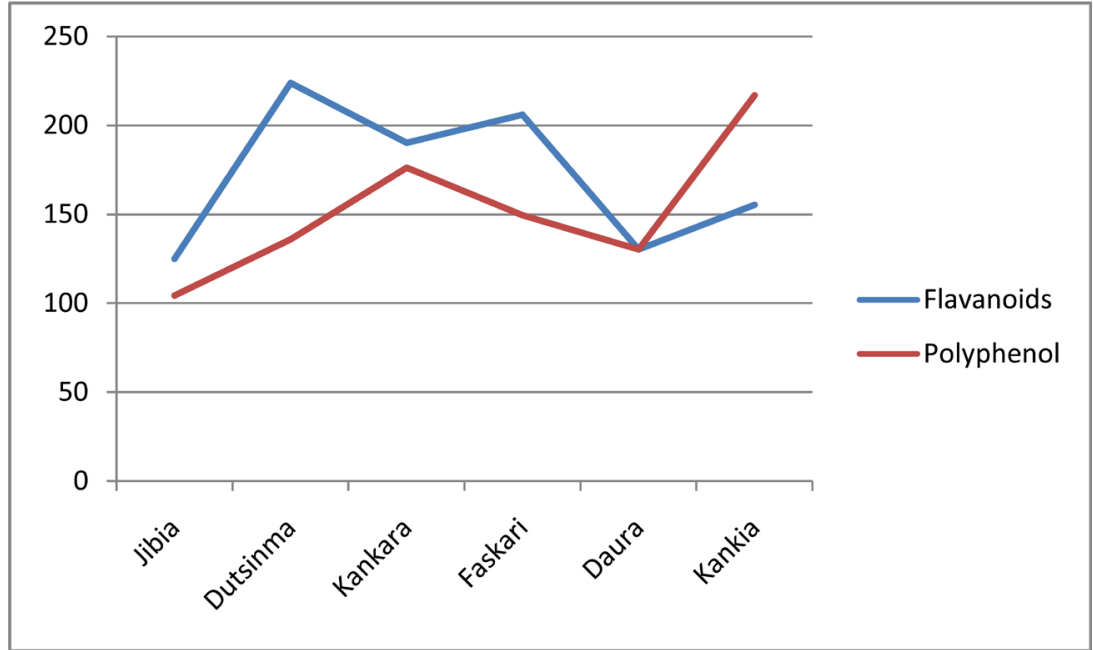

Figure 4. Line graph of flavonoid and polyphenol contents in lettuce from six Local Governments of Katsina State, Nigeria.

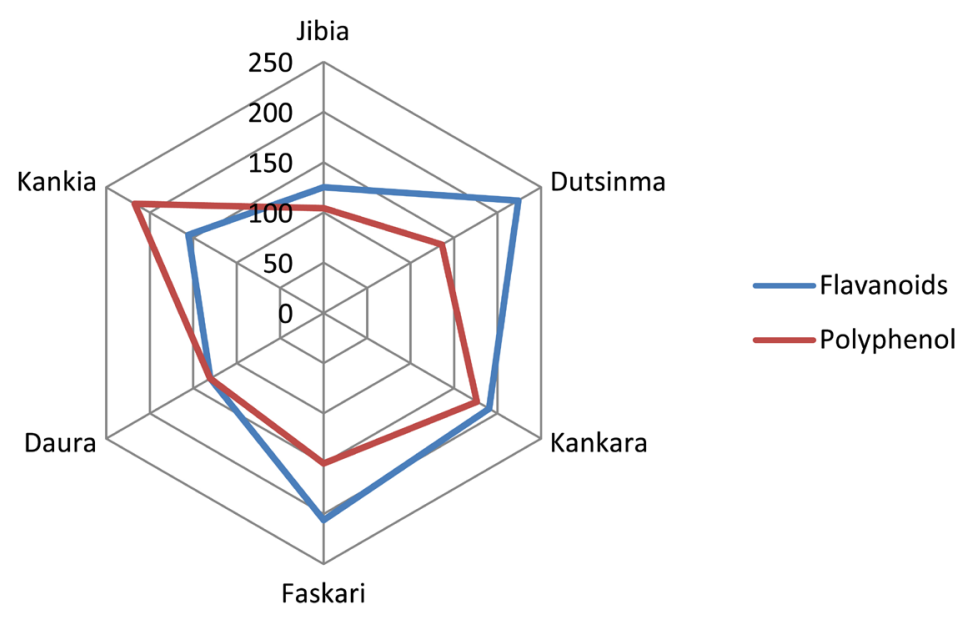

Figure 5. Radar graph of flavonoid and Polyphenol contents in lettuce from six local Governments of Katsina state, Nigeria.

Table 3. Comparative t-test of flavanoid and polyphenol contents from lettuce grown in six local Governments in Katsina State, Nigeria.

\begin{tabular}{cccccccc}
\hline Groups & $\mathrm{N}$ & Mean & Std. Dev. & Df & $\mathrm{T}$ & $\mathrm{p}$ & Decision \\
\hline Flavanoid & 6 & 171.84 & 40.92 & 10 & 0.844 & 0.419 & Not Significant. \\
Polyphenol & 6 & 152.24 & 39.53 & & & & \\
\hline
\end{tabular}

The concentration of each parameter is considered significant if $\mathrm{P} \leq 0.05$; where $\mathrm{N}=$ Sample size, Std. Dev $=$ Standard Deviation, $\mathrm{Df}=$ Degree of Freedom, $\mathrm{T}=\mathrm{t}$-test value, $\mathrm{P}=$ Alpha Value.

our model fit scenario that lettuces grown in the state has high antioxidant potential due to substantial amounts of their polyphenols and flavanoids. Phenolic compounds in these vegetables play the key role as primary antioxidants or free radical scavengers. The antioxidant activity of the phenolic compounds is mainly due to their redox properties, which can play an important role in absorbing and 
neutralizing free radicals, quenching singlet and triplet oxygen or decomposing peroxides (Osawa, 1994) [16]. The bioactivity of phenolics may be related to their ability to chelate metals, inhibit lipoxygenase and scavenge free radical (Mallavadhani et al., 2006; Lin et al., 2005) [19] [20]. The vegetables employed in this study are potentials in providing antimutagenic and anticarcinogenic properties in humans, when $\sim 1.0 \mathrm{~g}$ of the polyphenolic contents are consumed daily (Tanaka et al., 1998) [21]. The result of this study indicates that the vegetables employed especially onion can be used in management of diabetes mellitus since patients with diabetes mellitus are characterized with elevated level of oxidative damage, decreased level of antioxidant defenses and are prone to lipid abnormalities due to lipid peroxidation (Asayama et al., 1993) [22].

This study indicates a significant reduction in the risks for a variety of diseases upon feeding because Lettuces are polyphenol-rich vegetables (Kris-Etherton et al., 2002) [23]. Phenolic compounds possess multiple biological properties such as antitumor, antimutagenic and antibacterial properties and these activities might be related to their antioxidant activity. Polyphenols in plants are considered to be important ingredients in human diet. They are reported to exert a lot of biological effects such as antioxidant activity and inhibitory effects on carbohydrates hydrolyzing enzymes due to their ability to binds with protein (Griffiths and Moseley, 1980) [24]. This work is in line with the consumption of vegetables with high polyphenolic compound which can delay the digestion of starch since these compounds inhibit intestinal carbohydrates hydrolyzing enzymes (Lehmann and Robin, 2007) [25]. Drugs such as arcabose, miglitol and voglibose also perform this task. This study indicated that these vegetables possess potent antioxidant and antidiabetic potentials due to their possession of polyphenolic compounds and their ability to inhibit the activity of $\alpha$-glucosidase, $\alpha$-amylase and lipases (Oben et al., 2010; Kunga et al., 2010: Anon, 2011) [26] [27] [28].

\section{Conclusion}

Flavonoids and polyphenol contents of lettuce grown in Katsina were investigated in this work. The findings reveal that the studied vegetables are rich in flavonoids and polyphenols. These biomolecules can make great contribution in preventive medicine as they prevent carcinogenic infections and other terminal health challenges. In the light of our findings, we posit that these compounds be used to improve the immunocompetence of consumers of lettuce and therefore recommend further research (Victor M. et al., 2014, Gnimintakpa J. and Sa'ada A., 2016) [29] [30] in immunotherapeutics and pharmacology on flavonoids and polyphenol contents of lettuce grown in Katsina.

\section{References}

[1] Prior, R.L. and Cao, G. (2000) Antioxidant Phytochemicals in Fruits and Vegetables; Diet and Health Implications. Hort Science, 35, 588-592.

[2] Goldberg, G. (2003) Plants: Diet and Health. The Report of a British Nutrition 
Foundation Task Force. Blackwell Publishing Ltd., Oxford, 347. https://doi.org/10.1002/9780470774465

[3] Liu, S., Manson, J.E., Lee, I.M., Cole, S.R., Hennekens, C.H., Willett, W.C. and Buring, J.E. (2000) Fruit and Vegetable Intake and Risk of Cardiovascular Disease: The Women's Health Study. The American Journal of Clinical Nutrition, 72, 922-928.

[4] Djouss'e, L., Arnett, D.K., Coon, H., Province, M.A., Moore, L.L. and Ellison, R.C. (2004) Fruit and Vegetable Consumption and LDL Cholesterol: The National Heart Lung and Blood Institute Family Heart Study. The American Journal of Clinical Nutrition, 79, 213-217.

[5] Temple, N.J. and Gladwin, K.K. (2003) Fruit Vegetables and the Prevention of Cancer: Research Challenges. Nutrition, 19, 467-470.

https://doi.org/10.1016/S0899-9007(02)01037-7

[6] Hung, H.C., Joshipura, K.J., Jiang, R., Hu, F.B., Hunter, D., Smith-Warner, S.A., Colditz, GA. Rosner, B., Spiegelman, D. and Willett, W.C. (2004) Fruit and Vegetable Intake and Risk of Major Chronic Disease. Journal of the National Cancer Institute, 96, 1577-1584. https://doi.org/10.1093/jnci/djh296

[7] [WHO] World Health Organization (2002) The World Health Report 2002: Reducing Risks, Promoting Healthy Life. WHO, Geneva.

[8] [WHO] World Health Organization (2003) Diet Nutrition and the Prevention of Chronic Diseases. Report of a Joint WHO/FAO Expert Consultation. WHO Technical Report Series No. 916, WHO, Geneva.

[9] Orcutt, D.M. and Nilsen, E.T. (2000) The Physiology of Plants under Stress Soil and Biotic Factors. JohnWiley and Sons Inc., New York, 680 p.

[10] MacEvilly, C. and Peltola, K. (2003) The Effect of Agronomy Storage Processing and Cooking on Bioactive Substances in Food. In: Goldberg, G., Ed., Plants. Diet and Health, Blackwell Publishing Ltd., Oxford, 226-239.

https://doi.org/10.1002/9780470774465.ch12

[11] Seiger, D.S. (1998) Plant Secondary Metabolism. Kluwer Academic Publishers, Dordrecht, 592. https://doi.org/10.1007/978-1-4615-4913-0

[12] Crozier, A., Clifford, M. and Ashihara, H. (2006) Plant Secondary Metabolites: Occurrence Structure and Role in the Human Diet. Blackwell Publishing Ltd., Oxford, 384 p. https://doi.org/10.1002/9780470988558

[13] Giroh, D.Y., Waizah, Y. and Umar, H.Y. (2010) Technical Efficiency and Cost of Production among Gum Arabic Farmers in Jigawa State. Report and Opinion, 2, 52-57.

[14] Hugues, D. and Phillippe, D.L. (1995) African Gardens and Orchards Growing Vegetables and Fruits. Alphabet Publishers, Owerri.

[15] Atawodi, S.E. and Onaolapo, G.S. (2010b) Comparative In Vitro Antioxidant Potential of Different Parts of Ipomoea asarifolia, Roemer and Schultes, Guiera senegalensis J.F.Gmel and Anisopus mannii N.E.Brown. Brazilian Journal of Pharmaceutical Sciences, 46, 245-250. https://doi.org/10.1590/S1984-82502010000200011

[16] Osawa, T. (1994) Novel Natural Antioxidants for Utilization in Food and Biological Systems. Postharvest Biochemistry of Plant Food-Materials in the Tropics. Japan Scientific Press, Tokyo, 241-251.

[17] Sun, J., Chu, Y.F., Wu, X.Z. and Liu, R.H. (2002) Antioxidant and Antiproliferative Activities of Common Fruits. Journal of Agricultural and Food Chemistry, 50, 7449-7454. https://doi.org/10.1021/jf0207530

[18] Ramadeep, K.T. and Geoffrey, P.S. (2005) Antioxidant Activity in Different Frac- 
tions of Tomatoes. Food Research International, 38, 487-494. https://doi.org/10.1016/j.foodres.2004.10.016

[19] Mallavadhani, U., Sudhakar, A., Sathyanarayana, K.V.S., Mahapatra, A., Li, W. and Richard, B. (2006) Chemical and Analytical Screening of Some Edible Mushrooms. Food Chemistry, 95, 58-64. https://doi.org/10.1016/j.foodchem.2004.12.018

[20] Lin, H.F., Traver, D., Zhu, H., Dooley, K., Paw, B.H., Zon, L.I. and Handin, R.I. (2005) Analysis of Thrombocyte Development in CD41-GFP Transgenic Zebrafish. ZFIN Publication' Blood, 106, 3803-3810. https://doi.org/10.1182/blood-2005-01-0179

[21] Tanaka, M., Kuie, C.W., Nagashima, Y. and Taguchi, T. (1998) Applications of Antioxidative Maillard Reaction Products from Histidine and Glucose to Sardine Products. Nippon Suisan Gakaishi, 54, 1409-1414.

https://doi.org/10.2331/suisan.54.1409

[22] Asayama, K., Uchida, N., Nwakene, T., Hayashibe, H., Dobashi, K., Amemia, S., Kato, K. and Nakazawa, S. (1993) Antioxidants in the Serum of Children with Insulin-Dependent Diabetes Mellitus. Free Radical Biology and Medicine, 15, 597-602. https://doi.org/10.1016/0891-5849(93)90162-N

[23] Kris-Etherton, P.M., Hecker, K.D., Bonanome, A., Coval, S.M., Binkoski, A.E., Hilpert, K.F., Griel, A.E. and Etherton, T.D. (2002) Bioactive Compounds in Foods: Their Role in the Prevention of Cardiovascular Disease and Cancer. American Journal of Medicine, 113, 71S-88S. https://doi.org/10.1016/S0002-9343(01)00995-0

[24] Wynne Griffiths and Gwyn Moseley (1980) The Effect of Diets Containing Field Beans of High or Low Polyphenolic Content on the Activity of Digestive Enzymes in the Intestines of Rats. Journal of the Science of Food and Agriculture, 31, 255-259. https://doi.org/10.1002/jsfa.2740310307

[25] Lehmann, U. and Robin, F. (2007) Slowly Digestible Starch-Its Structure and Health Implications: A Review. Trends Food Science and Technology, 18, 346-355. https://doi.org/10.1016/j.tifs.2007.02.009

[26] Oben, J.A., Patel, T., Mouralidarane, A., Samuelsson, A.M., Matthews, P., Pombo, J., Morgan, M., McKee, C., Soeda, J., Novelli, M., Poston, L. and Taylor, P. (2010b) Maternal Obesity Programmes Offspring Development of Non-Alcoholic Fatty Pancreas Disease. Biochemical and Biophysical Research Communications, 394, 24-28. https://doi.org/10.1016/j.bbrc.2010.02.057

[27] Kunga, M.R., Thayumanavan, B., Palvannan, T. and Rajaguru, P. (2010) Inhibitory Effect of Leaves of Gymnema montanum on $\alpha$ Glucosidase and $\alpha$ Amylase Activity and Relationship with Polyphenolic Content. Medicinal Chemistry Research, 19, 948-961. https://doi.org/10.1007/s00044-009-9241-5

[28] Anonymous (2011) Herbal Supplements.

[29] Marcus, V., Mohammed, M.S., Mustapha, M., Igwilo, I. and Gnimintakpa, J. (2014) Extractibility of Thevetia peruviana Glycoside Using Various Organic Solvents. Journal of Biology, Agriculture and Healthcare, 4.

[30] Gnimintakpa, J. and Abdullahi, S. (2016) Physicochemical and Proximate Analysis of Extracts from Citrus sinensis of Dutsinma, Katsina State, Nigeria. Open Access Library Journal, 3, e2495. 
Submit or recommend next manuscript to OALib Journal and we will provide best service for you:

- Publication frequency: Monthly

- 9 subject areas of science, technology and medicine

- Fair and rigorous peer-review system

- Fast publication process

- Article promotion in various social networking sites (LinkedIn, Facebook, Twitter, etc.)

- Maximum dissemination of your research work

Submit Your Paper Online: Click Here to Submit

Or Contact service@oalib.com 